\title{
Pierce's Disease of Grapevines: Identification of the Primary Vectors in North Carolina
}

\author{
Ashley L. Myers, Turner B. Sutton, Jorge A. Abad, and George G. Kennedy
}

First, second, and third authors: Department of Plant Pathology, and fourth author: Department of Entomology, North Carolina State University, Raleigh 27695.

Current address of A. L. Myers: Surry Community College, Dobson, NC.

Current address of J. A. Abad: U.S. Department of Agriculture, APHIS, Plant Germplasm Quarantine Program, Bldg. 580, BARC-E, Beltsville, MD 20705.

Accepted for publication 12 April 2007.

\begin{abstract}
Myers, A. L., Sutton, T. B., Abad, J. A., and Kennedy, G. G. 2007. Pierce's disease of grapevines: Identification of the primary vectors in North Carolina. Phytopathology 97:1440-1450.

In the past 10 years, the winegrape industry in the southeastern United States has experienced rapid growth; however, further expansion may be inhibited by Pierce's disease (PD). Epidemiological studies were conducted to identify the primary vectors of Xylella fastidiosa, the cause of $\mathrm{PD}$ of grape, by surveying sharpshooter population dynamics in the eastern Piedmont and Coastal Plain regions of North Carolina. Sharpshooter species were assessed for the presence of X. fastidiosa in the field. Leafhoppers were trapped in three vineyards in the eastern Piedmont and one vineyard in the northeastern Coastal Plain in 2004 and

orbona, Graphocephala versuta, Paraphlepsius irroratus, and Agalliota constricta. Adult specimens of $O$. orbona, $G$. versuta, and $P$. irroratus were tested for the presence of $X$. fastidiosa by nested polymerase chain reaction. In all, $27 \%$ of $O$. orbona, $28 \%$ of $G$. versuta, and $33 \%$ of $P$. irroratus trapped were positive for $X$. fastidiosa over the two seasons. Transmission experiments demonstrated that both $O$. orbona and G. versuta have the ability to transmit $X$. fastidiosa to grape. These vectors are likely to be important in all winegrowing regions of the Southeast, because their presence has been documented throughout the southern states. In DNA analyses, $X$. fastidiosa strains from insects trapped in North Carolina were genetically similar to one another and to the known "PD strain" from California. This is the first report of these two leafhopper species transmitting $X$. fastidiosa to grapevines in the Southeast.
\end{abstract} 2005. Four insects were identified as most abundant: Oncometopia
Pierce's disease (PD) of grapevines is caused by a strain of the bacterium Xylella fastidiosa (48), an endophytic bacterial pathogen that resides in the xylem of plants (11) and is transmitted plant-to-plant by xylem-feeding insects such as sharpshooters (subfamily Cicadellinae in leafhopper family Cicadellidae) and spittlebugs (family Cercopidae) (14). Within the United States, the occurrence of PD ranges from Florida to Texas and into California and, in the Southeast, decreases with increasing distance from the Gulf of Mexico (20). Recently, PD has caused an estimated $\$ 13$ million in losses in California's Temecula Valley alone (Wine Institute, personal communication). Moreover, in a single vineyard in the eastern Piedmont of North Carolina, the incidence of seriously affected vines or vine death due to PD increased from $24 \%$ in 2001 to $54 \%$ in 2002 (T. B. Sutton, unpublished data).

$X$. fastidiosa invades the host following inoculation via sharpshooter vectors (14) and spittlebugs (40). As of 2004, 39 species and 19 genera of Cicadellinae have been shown to vector $X$. fastidiosa (39). Most sucking insects that feed in the xylem sap are potential vectors; however, vector species differ in their transmission efficiency or competence (38). The red-headed sharpshooter, Xyphon (Carneocephala) fulgida (Nottingham); green sharpshooter, Draeculacephala minerva (Ball); blue-green sharpshooter, Graphocephala atropunctata (Signoret); glassywinged sharpshooter, Homoladisca coagulata (Say); and Oncometopia spp. are abundant insect vector species often found in affected crops or adjacent fields (39).

Corresponding author: A. L. Myers; E-mail address: myersa@ surry.edu

doi:10.1094/PHYTO-97-11-1440

(c) 2007 The American Phytopathological Society
Recently, winegrape production in North Carolina and other states of the Southeast has expanded rapidly to include cultivation of Vitis vinifera and French-American hybrid grape plants. Much of the expansion has been in the central and western Piedmont and, in these regions, PD is the single most formidable obstacle to growing vinifera grapes (A. H. Purcell, personal communication) and limits the areas of the Southeast where production of $V$. vinifera and French-American hybrids are viable (Wolf and Poling, personal communication). However, within the southeastern United States, most work has been done on Muscadinia rotundifolia and little is known about the vectors, reservoir hosts of Xylella fastidiosa, and methods of controlling PD on V. vinifera.

A better understanding of the biology and epidemiology of PD on $V$. vinifera in the Southeast would enable growers to better manage PD in their vineyards. Unfortunately, many factors affecting the development of PD in the Southeast, including the identity of principle vectors, are unknown. Consequently, the objectives of this study were to better understand the epidemiology of PD in the North Carolina by (i) surveying sharpshooter populations in the eastern Piedmont and Coastal Plain regions, (ii) identifying potential sharpshooter vectors by polymerase chain reaction (PCR) assays, (iii) conducting greenhouse experiments with potential vectors to determine transmission ability, and (iv) performing analyses of $X$. fastidiosa $\mathrm{PCR}$ products to provide information on the populations of $X$. fastidiosa that sharpshooters in North Carolina are carrying.

\section{MATERIALS AND METHODS}

Insect surveys in four North Carolina vineyards. In order to determine the leafhopper species present in vineyards in North Carolina, yellow sticky traps $(15.3$ by $30.6 \mathrm{~cm}$ ) (Great Lakes 
IPM, Vestaburg, MI) were placed in three vineyards in the eastern Piedmont (vineyard 1, Wake County; vineyard 2, Chatham County; and vineyard 3, Alamance County) and one vineyard in the northeastern Coastal Plain (vineyard 4, Currituck County) from 13 May (day 134) to 10 September (day 254) 2004 and 6 April (day 96) to 22 August (day 234) 2005, in areas where PD is endemic and has been well documented (19). Trapping was initiated earlier in 2005 because data collected in 2004 indicated that leafhoppers were present prior to May and early-season infection is reported to be most significant (12). Vineyard 1 was a 5 -year-old $V$. vinifera vineyard near Raleigh, $\mathrm{NC} \approx 1.7$ ha in size with 1,586 vines. Vineyard 2 was a 7-year-old vineyard near Pittsboro, NC of $\approx 1$ ha comprising $614 \mathrm{~V}$. vinifera and FrenchAmerican hybrid grapevines. Vineyard 3, in Mebane, NC, was $\approx 1.7$ ha and contained 3,459, 4-year-old $V$. vinifera and FrenchAmerican hybrids. Vineyard 4 was 14 years old and contained a combination of $V$. vinifera, French-American hybrid, and muscadine grape plants located near the Outer Banks of North Carolina in the northeastern Coastal Plain.

Traps were prepared by placing a 4-cm strip of clear, fibrous tape (Clear Duck Tape; Henkel Consumer Adhesives, Inc., Avon, $\mathrm{OH})$ on the tops of both sides of the trap to prevent tearing in strong winds. Eight traps were placed along the perimeter of each vineyard, positioned on the cordon wires $(\approx 1 \mathrm{~m}$ aboveground), and fastened with two binder clips on the upper left and right corners of the trap. Traps were replaced every 14 days and stored at $4^{\circ} \mathrm{C}$. Each trap was examined for the presence of leafhoppers and the most abundant leafhoppers were counted and recorded. A subsample (the size of the subsample varied depending on insect availability but ranged from one to eight insects per trap per trapping period) of each species was selected arbitrarily and removed from traps, using Histoclear (RA Lamb LLC, Apex, NC) to dissolve the adhesive, then stored at $-20^{\circ} \mathrm{C}$ for PCR analysis. Another subsample $(n \approx 144)$ of each species collected in 2004 was preserved in $70 \%$ ethanol for identification. The leafhoppers initially were identified to the genus level and the four most abundant leafhoppers were identified to the species level under the direction of personnel at the North Carolina State University Plant Disease and Insect Clinic using Cicadellinae references (10,50,51). Nomain Insecta Nearctica, A Check List of Insects of North America was checked to get consulted generic assignments (33), and the vineyard specimens were compared with specimens in the North Carolina State University Insect Collection.

Detection of $X$. fastidiosa in potential vectors with nested PCR. The sharpshooters Oncometopia orbona (F.), G. versuta (Say), and Paraphlepsius irroratus (Say) were tested for the presence of $X$. fastidiosa. Insect heads were severed from their bodies and pinned through their mouthparts with no. 3 stainless steel insect pins (Morpho, Czech Republic) according to the protocol developed by Bextine et al. (5). Pinned heads were placed into $1.5-\mathrm{ml}$ microcentrifuge tubes with $250 \mu \mathrm{l}$ of phosphate-buffered saline (PBS; $\mathrm{pH} 7.0$ ) and incubated at $-20^{\circ} \mathrm{C}$ overnight. Bacterial DNA was extracted using vacuum infiltration as a pre-extraction method (5). Briefly, lids to microcentrifuge tubes that contained pinned insects were opened and tubes were placed into the vacuum chamber. A vacuum was applied at $80 \mathrm{~cm}$ $\mathrm{Hg}$ for $15 \mathrm{~s}$, then released slowly to separate the bacteria from the insect mouthparts. This procedure was repeated twice. After vacuum pre-extraction, DNA extraction was completed by using the DNA insect tissue extraction procedure from the Qiagen DNeasy Tissue Kit (Qiagen Inc., Hercules, CA).

Nested PCR (35) was used to maximize and visualize the DNA amplification. Using as a template $5 \mu \mathrm{l}$ of DNA extracted from the insect mouthparts, DNA specific to $X$. fastidiosa was amplified using two pairs of oligonucleotide primers (Invitrogen Corporation, Frederick, MD) developed by Pooler and Hartung (34). The external primers 272-1 and 272-2 generate a 700-nucleotide amplicon, while internal primers 272-1-int and 272-2-int amplify a 500-nucleotide PCR product. Amplifications were performed in a $25-\mu \mathrm{l}$ volume containing sterile distilled water, $2.5 \mathrm{mg}$ of $10 \times$ polymerase buffer, $4 \mathrm{mM}$ each dNTP, $0.15 \mu \mathrm{g}$ of each primer, $2.5 \% \mathrm{MgCl}_{2}$, and $1 \mathrm{U}$ of Taq polymerase (Promega Corp., Madison, WI). Magnesium chloride $(2.4 \%)$ was used in the nested amplification. Positive controls consisted of $4 \mu \mathrm{l}$ of water and $1 \mu \mathrm{l}$ of $X$. fastidiosa PCR positive isolated from an isolate of $X$. fastidiosa from grape growing on PD2 agar medium (8). Negative controls were $5 \mu \mathrm{l}$ of sterile water with PCR master mix. Preparation of the master mix and aliquoting of samples was done in The Clone Zone with HEPA Filter (USA Scientific, Inc., Ocala, FL) for maximum sterilization. For both amplifications, the same PTC-100 Thermal Cycler (MJ Research Inc., Watertown, PA) profile was used (35). Nested PCR product $(5 \mu \mathrm{l})$ was analyzed by $1 \%$ agarose horizontal gel electrophoresis in Tris-borate-EDTA buffer. Gels were stained with ethidium bromide and bands were visualized under UV light. Amplicons were characterized as positive or negative. DNA began to degrade during testing of $P$. irroratus and the amount of extracted DNA utilized as a template was reduced to $2.5 \mu \mathrm{l}$.

Greenhouse transmission bioassays. Seedlings of the $X$. fastidiosa-susceptible cv. Chardonnay were used in the greenhouse transmission experiments. Some Chardonnay seedlings were 1-year-old vines planted during summer 2004 and pruned back to two or three buds during March 2005 to generate new growth. The grapevines were grown in $15-\mathrm{cm}$ clay pots in an enclosed greenhouse with temperatures maintained at approximately $25^{\circ} \mathrm{C}$. $O$. orbona and $G$. versuta were selected for the greenhouse experiments because (i) both genera have been shown to transmit the PD strain of $X$. fastidiosa (1), (ii) both species have been shown to transmit $X$. fastidiosa to peach $(45,46)$, and (iii) both $O$. orbona (personal observation) and $G$. versuta reproduce on grape (1).

Field-captured sharpshooters were used in transmission experiments to test for natural infectivity. All adult sharpshooters used for infectivity tests were collected from vineyard 1, except 36 $G$. versuta which were captured at vineyard 3. Sharpshooters were collected on multiple days during the period of peak trap catches in 2005.

$O$. orbona insects typically were captured on the base of new shoots by tapping them into sweep nets. G. versuta insects were caught with a sweep net by sweeping the upper canopy of the vine. Once caught, the insects were placed into plastic bags and stored in the shade until transferred within $2 \mathrm{~h}$ to the experimental plants.

Plastic cages (15 cm in diameter) with mesh or nylon tops were used to cage adult insects and provide insects with access to the entire plant. The soil of potted plants used in the $G$. versuta transmission experiments was covered with one layer of cheesecloth to facilitate removal of insects. Five sharpshooters were caged on the majority of plants; however, one to seven insects were placed on some plants depending on size and the available supply of the insect. $O$. orbona insects were taken from the bags and manually placed onto the test plants. G. versuta insects were aspirated into a $250-\mathrm{ml}$ Erlenmeyer flask and the flask was placed in the cage along with the vine to allow the insects to escape. Insects were allowed to feed undisturbed for 6 days in order to maximize inoculation. On day 6 , sharpshooters were removed from test plants and stored at $-20^{\circ} \mathrm{C}$ for eventual testing. Caged plants with five to seven insects were placed into plastic bags and exposed to $\mathrm{CO}_{2}$ for easier removal of insects. After exposure to the insects, egg masses found on the plants were removed manually and vines were treated with imidacloprid (Admire 2F; Bayer CropScience, Durham, NC) to prevent reinfestation with nymphs. Inoculated plants were kept in propagation cages covered with $500 \mu \mathrm{m}$ of Nitex Bolting Cloth (Wilco, Buffalo, NY) until all testing was complete in order to prevent possible inoculation of healthy plants in the greenhouse. One week after the insects were 
removed, vines were treated with myclobutanil (Nova 40W; DowAgrosciences, Indianapolis, IN) and azoxystrobin (Abound; Syngenta Inc., Greensboro, NC) to control powdery mildew. All experiments had at least two negative controls which were not exposed to insects.

Plants were held for $\approx 4$ months, watered daily, and monitored weekly for typical PD symptom development $(17,21,22,32)$. Mycobutanil was applied as needed for powdery mildew control. To test for the presence of $X$. fastidiosa, leaf petioles from all plants were collected 3 months post inoculation. Petioles from symptomatic leaves were chosen when available. Petioles from leaves on nonsymptomatic plants used in $O$. orbona experiments were chosen from the base of vines because of basal shoot feeding preferences of the insect. Petioles from nonsymptomatic G. versuta experiments were collected arbitrarily from the entire plant because G. versuta prefers to feed on leaf tissue. Samples were stored at $4{ }^{\circ} \mathrm{C}$ until tested for $X$. fastidiosa. We did not attempt to isolate $X$. fastidiosa from the plants used in greenhouse transmission bioassays.

A commercially available double-antibody sandwich enzymelinked immunosorbent assay (ELISA) test kit (Agdia Inc., Elkhart, IN) was used to test the 166 grapevines from the greenhouse experiments. Petiole tissue samples $(\approx 0.3$ to $0.5 \mathrm{~g})$ were obtained from each vine. If symptoms were present, petioles from symptomatic leaves were used (previously noted). Using a sterile razor blade and cutting board, samples were sliced lengthwise down the center of the petiole and one half of each petiole was stored at $4^{\circ} \mathrm{C}$ for further testing with PCR. The remaining pieces were cut widthwise into several very small pieces $\approx 1 \mathrm{~mm}$ in length. Samples were placed into centrifuge tubes with screw caps (Sarstedt Ag \& Co, Germany) with $5 \mathrm{ml}$ of Agdia grape extraction buffer (Agdia Inc.). Tissue was macerated with Brinkmann PTMR 3000 Homogenizer (Biomatic Technologies, Stoughton, MA) and ELISA was performed according to test kit instructions. Positive and negative controls were included. Results were quantified by an EMAX Precision Microplate Reader (Molecular Devices Corporation, Sunnyvale, CA) set at a wavelength of $490 \mathrm{~nm}$. To determine the positive cutoff value, three times the standard deviation of all known negative controls was added to the mean of all negative control wells. A sample with an optical density above this cutoff value was considered positive and below the cutoff value, negative.

Immunocapture of $X$. fastidiosa followed by nested PCR was performed on a sample $(n=6)$ of plants providing a positive ELISA signal to confirm the validity of the ELISA tests. Fresh petioles were sliced lengthwise and into 1-mm disks, and covered with Tris- $\mathrm{Cl}$ at $50 \mathrm{mmol}_{1}$ iter $^{-1}, \mathrm{pH} 7.5$, buffer in a $1.5-\mathrm{ml}$ microcentrifuge tube. Samples were incubated overnight at $4^{\circ} \mathrm{C}$. Vacuum extraction was performed as described above (5). After the vacuum extraction, the buffer was pipetted into clean $1.5-\mathrm{ml}$ microcentrifuge tubes and plant debris were discarded. Immunocapture of $X$. fastidiosa was conducted according to methods developed by Pooler et al. (35). The Dynabead/bacteria complex was separated from the mixture with an 821-Gauss magnet, which drew the beads to the side of the tube. The supernatant was removed by pipette and discarded. The bead/bacteria complex was washed once with $300 \mu \mathrm{l}$ of PBS, suspended in $5 \mu \mathrm{l}$ of sterile distilled water, and the DNA was exposed by heat shocking the bacteria for $2 \mathrm{~min}$ at $98^{\circ} \mathrm{C}$, then $2 \mathrm{~min}$ on ice, repeated three times.

The DNA eluant $(1 \mu \mathrm{l})$ then was added to the PCR master mix as described above for the insect assays. Positive controls consisted of $4 \mu \mathrm{l}$ of plant tissue extract and $1 \mu \mathrm{l}$ of $X$. fastidiosa obtained from bacteria growing on PD2 agar medium (9). Negative controls were $5 \mu \mathrm{l}$ of sterile water with no bacteria or plant tissue and $5 \mu \mathrm{l}$ of plant tissue extract from experimental controls. PCR and visualization of PCR results were conducted as described previously.
Sequences from North Carolina insects. Amplified PCR products $(n=46)$ from the insect assays were sequenced in both orientations. Sequencing was conducted following the specifications of the North Carolina State University Genomic Research Laboratory (GRL). Nested PCR products corresponding to a fragment of a hypothetical protein gene of $X$. fastidiosa were cleaned with the Qiagen PCR Purification Kit (Qiagen Inc.). Purified DNA $(\mu \mathrm{l})$ was used as a template in a $10-\mu \mathrm{l}$ reaction that contained sterile water, BigDye mix/dilution buffer $(1: 1)$, and $0.15 \mu \mathrm{g}$ of internal primer, either 272-1-int or 272-2-int (Invitrogen Corporation). Reactions were done with the PTC-100 Thermal Cycler (MJ Research Inc.) using the $X$. fastidiosa profile described above. After amplification, $10 \mu \mathrm{l}$ of DI water was used to bring the volume to $20 \mu \mathrm{l}$. Cleanup of amplicons was done following the Qiagen DyeEx (Qiagen Inc.) kit instructions. The clean amplicons were taken to the GRL to be run on capillary sequencers.

Sequences were assembled with the program Vector NTI (Invitrogen Corp.). Sequences of each sample of X. fastidiosa were compared with sequences obtained in silico from GenBank and National Center for Biotechnology Information (NCBI) BLAST. Multiple sequence alignments of nucleotides were performed using CLUSTAL X (43) and Bioedit (18) with default parameters. Phylogenetic trees were obtained from the data by the Neighbor-joining method of pairwise comparison using 1,000 bootstrap iterations and visualized with the program MEGA, version 2.01 (27).

Further analyses were conducted in SNAP Workbench (36). Sequences were imported into SNAP Workbench in Fasta format, aligned with CLUSTAL W version 1.7 (44), and converted to Phylp format (13). SNAP Map (3) collapsed sequences into haplotypes. A phylogenetic analysis with unweighted parsimony performed with PAUP 4.0 (42) yielded a single most-parsimonious tree visualized in Treeview (31). In examining the possibility of recombination, SNAP Clade (29) was used to generate a site compatibility matrix. The compatibility matrix was visualized in SNAP matrix (29) and one variable site creating homoplasy was removed with no affect on the distribution of haplotypes.

To test for pairwise population subdivision of $X$. fastidiosa between the insect species, SNAP Map (3) was used to generate the sequence file and Seqtomatrix (24) converted the sequence file into a distance matrix. Permtest, based on nonparametric permutations of Monte Carlo simulations (24), nearest neighbor statistic (23), and ranked Z (24) calculated Hudson's test statistics $\mathrm{K}_{\mathrm{ST}}, \mathrm{K}_{\mathrm{S}}, \mathrm{K}_{\mathrm{T}}, \chi^{2}, \mathrm{Z}, \mathrm{H}_{\mathrm{ST}}, \mathrm{H}_{\mathrm{S}}, \mathrm{H}_{\mathrm{T}}$, and $\mathrm{S}_{\mathrm{nn}}$, where $\mathrm{K}_{\mathrm{ST}}=1-\left(\mathrm{K}_{\mathrm{S}} / \mathrm{K}_{\mathrm{T}}\right)$, $\mathrm{K}_{\mathrm{S}}=$ average number of differences between sequences within subpopulations, $\mathrm{K}_{\mathrm{T}}=$ average number of differences between sequences regardless of locality, $\chi^{2}=$ test of allele frequencies in samples from different localities, $Z=$ weighted sum of $Z_{1}$ and $Z_{2}$, where $Z_{i}$ is the average of the ranks of all the $d_{i j, l k}$ values for pairs of sequences from within locality $i, \mathrm{H}_{\mathrm{ST}}=1-\left(\mathrm{H}_{\mathrm{S}} / \mathrm{H}_{\mathrm{T}}\right), \mathrm{H}_{\mathrm{S}}=$ weighted average of estimated haplotypes diversities in subpopulations, $\mathrm{H}_{\mathrm{T}}$ = estimation of haplotypes diversity in the total population, and $S_{n}=$ how often the "nearest neighbor" (in sequence space) of sequences are from the same locality in geographic space. Sequenced-based statistics $\mathrm{K}_{\mathrm{ST}}, \mathrm{K}_{\mathrm{S}}, \mathrm{K}_{\mathrm{T}}$, and $\mathrm{Z}$ were chosen for the analysis because hosts sample sizes varied from 1 to 24 and sequenced-based statistics are more powerful when sample sizes are low (24). In addition, guidelines in Hudson et al. (24) suggest placing the most confidence in the $\mathrm{Z}$ statistic because the calculated $\mathrm{H}_{\mathrm{T}}>0\left(\mathrm{H}_{\mathrm{T}}>1-[1 / \mathrm{min}(\right.$ sample sizes $\left.)]\right)$ and sample sizes are unequal.

\section{RESULTS}

Insect surveys. In 2004, sticky traps caught a total of nine species of leafhoppers and one species of spittlebug across all of the vineyards surveyed. Three leafhopper species, identified as 
G. versuta, Agalliota constricta, and $P$. irroratus, were the most abundant species trapped and each exceeded $2 \%$ of the leafhoppers trapped (Table 1). O. orbona trap catches were $\geq 2 \%$ of the total leafhoppers caught in six of the eight experimental years (Table 1). Other species trapped averaged $2 \%$ of the remaining Cicadelline populations and were grouped into the category "other."

The greatest numbers of $O$. orbona were trapped in all vineyards during the first two trapping periods, from 13 May to 9 June (days 134 to 161), with an additional peak in vineyard 3 at day 240 (Fig. 1A). In 2005, catches were highest during trapping periods extending from 17 May to 28 June (days 137 to 179) (Fig. 1B). In 2005, traps were placed in the vineyards just prior to budburst on 6 April (day 96), and a few O. orbona were trapped on the beginning trap date in all vineyards except vineyard 4 . Overall, trap catches of $O$. orbona generally were higher in vineyard 1 and lowest in vineyard 4 during the 2 years.

In 2004, trap catches of $G$. versuta began increasing in June and peaked in late June to early July (days 165 to 193) in each vineyard (Fig. 2A). In 2005, catches also began to increase in June, peaking in late June to early July, with the exception of vineyard 3 , in which catches peaked $\approx 3$ weeks later than 2004 (Fig. 2B). Very large numbers of $G$. versuta were trapped in vineyard 3 both seasons, with traps totaling over 2,200 individuals when the catch level was highest. Similar to O. orbona, the fewest individuals of $G$. versuta were trapped in vineyard 4 in both seasons.

The greatest numbers of $P$. irroratus were trapped in May in both years of the study (Fig. 3). In 2004, the highest trap catches were recorded during the trapping period that extended from 13 May to 27 May (days 134 to 148), the first period that traps were in the vineyards (Fig. 3A). In 2005, catches increased rapidly in mid-May and were highest from 17 May to 17 June (days 137 to 168) (Fig. 3B). Trap catches were lowest in vineyards 2 and 4 each year.

In 2004, trap catches of $A$. constricta began to increase in June and peaked in early July in each vineyard (days 173 to 197) (Fig. 4A). A second, smaller peak was detected during trapping periods extending from 30 July to 10 September (days 212 to 254), coincident with the emergence of second-generation adults. In 2005 , the populations again began to increase in June and in vineyard 3, and peaked 1 week earlier than in 2004 (Fig. 4B).
Smaller peaks were observed on trapping dates 6 to 20 April (days 96 to 110) and 9 to 22 August (days 221 to 234) in 2005. Very large numbers were trapped in vineyard 3 in both seasons, with 2004 traps totaling over 1,150 individuals and 2005 traps totaling over 2,250 individuals during the peak trapping periods. Similar to the other leafhoppers, vineyard 4 had the lowest number of catches.

Leafhopper species caught on yellow sticky traps during 2004 and 2005 varied in relative composition between the central Piedmont and Coastal Plain. In 2004, 54\% of the leafhoppers caught in central Piedmont vineyards were G. versuta, compared with only $16 \%$ in the vineyard in the Coastal Plain. In contrast, $64 \%$ of the leafhoppers trapped in the Coastal Plain were A. constricta compared with $38 \%$ in the Piedmont. The relative proportion of $P$. irroratus was greater in the Coastal Plain vineyard than in the Piedmont vineyards. O. orbona composed approximately $2 \%$ of the catches in both locations. In 2005, the relative proportion of each species trapped in the Piedmont vineyards was similar. Proportionately fewer A. constricta were captured in the Coastal Plain vineyard in 2005, and more $O$. orbona, P. irroratus, and $G$. versuta were captured than in 2004.

Detection of $X$. fastidiosa in potential vectors with nested PCR. Among all vineyards surveyed in this study, 32 and $21 \%$ of the O. orbona tested positive for X. fastidiosa in 2004 and 2005, respectively, yielding a 500-bp amplicon in the nested PCR. In 2004 , most positives ( 7 of 11) were from the trapping date 13 to 27 May whereas, in 2005, all insects tested $(n=7)$ from 20 April to 3 May were positive. The number of $O$. orbona insects that tested positive decreased in late May to early June $(n=25)$ to $\approx 0$. Assay results across vineyards 1,2, and 3 from trapping date 3 through 17 May were discarded due to an error in testing.

Among the four vineyards surveyed, 38 and $19 \%$ of adult G. versuta from 2004 and 2005 , respectively, tested positive for $X$. fastidiosa. In 2004, most positives (7 of 15) were from the trapping date 13 to 27 May whereas, in 2005, most positives (4 of 6) were found from 6 to 20 April. None of the insects tested from July 2004 were positive. X. fastidiosa-positive G. versuta were collected from all vineyards during the sampling years.

In all, 48 and $18 \%$ of $P$. irroratus tested positive for $X$. fastidiosa in 2004 and 2005, respectively, among the four vineyards. In 2004, the most positives ( 8 of 12) occurred during the 13 to 27

TABLE 1. Number of leafhoppers trapped in four North Carolina vineyards in 2004 and 2005 and the percent composition of the most abundant species

\begin{tabular}{|c|c|c|c|c|c|c|}
\hline \multirow[b]{2}{*}{ Leafhopper species } & \multicolumn{3}{|c|}{2004} & \multicolumn{3}{|c|}{2005} \\
\hline & Vineyard $^{\mathrm{y}}$ & Number trapped & Percent & Vineyard ${ }^{y}$ & Number trapped & Percent \\
\hline Graphocephala versuta & $\begin{array}{l}1 \\
2 \\
3 \\
4\end{array}$ & $\begin{array}{r}2,206 \\
2,240 \\
5,076 \\
138\end{array}$ & $\begin{array}{l}55 \\
64 \\
51 \\
16\end{array}$ & $\begin{array}{l}1 \\
2 \\
3 \\
4\end{array}$ & $\begin{array}{r}1,848 \\
2,198 \\
4,560 \\
113\end{array}$ & $\begin{array}{l}50 \\
63 \\
40 \\
18\end{array}$ \\
\hline Oncometopia orbona & $\begin{array}{l}1 \\
2 \\
3 \\
4\end{array}$ & $\begin{array}{r}264 \\
56 \\
50 \\
20\end{array}$ & $\begin{array}{l}6 \\
2 \\
1 \\
2\end{array}$ & $\begin{array}{l}1 \\
2 \\
3 \\
4\end{array}$ & $\begin{array}{r}142 \\
102 \\
161 \\
58\end{array}$ & $\begin{array}{l}4 \\
3 \\
1 \\
9\end{array}$ \\
\hline Paraphelpsius irroratus & $\begin{array}{l}1 \\
2 \\
3 \\
4\end{array}$ & $\begin{array}{r}291 \\
165 \\
252 \\
74\end{array}$ & $\begin{array}{l}7 \\
5 \\
3 \\
9\end{array}$ & $\begin{array}{l}1 \\
2 \\
3 \\
4\end{array}$ & $\begin{array}{r}452 \\
102 \\
380 \\
88\end{array}$ & $\begin{array}{r}12 \\
3 \\
3 \\
14\end{array}$ \\
\hline Agalliota constricta & $\begin{array}{l}1 \\
2 \\
3 \\
4\end{array}$ & $\begin{array}{r}1,142 \\
965 \\
4,433 \\
535\end{array}$ & $\begin{array}{l}28 \\
27 \\
45 \\
64\end{array}$ & $\begin{array}{l}1 \\
2 \\
3 \\
4\end{array}$ & $\begin{array}{r}1,068 \\
1,027 \\
6,213 \\
290\end{array}$ & $\begin{array}{l}29 \\
29 \\
54 \\
47\end{array}$ \\
\hline Other species ${ }^{\mathrm{z}}$ & $\begin{array}{l}1 \\
2 \\
3 \\
4\end{array}$ & $\begin{array}{r}128 \\
98 \\
127 \\
74\end{array}$ & $\begin{array}{l}3 \\
3 \\
1 \\
9\end{array}$ & $\begin{array}{l}1 \\
2 \\
3 \\
4\end{array}$ & $\begin{array}{r}167 \\
72 \\
113 \\
72\end{array}$ & $\begin{array}{r}5 \\
2 \\
1 \\
12\end{array}$ \\
\hline
\end{tabular}

y Vineyards 1, 2, and 3 were located in central North Carolina. Vineyard 4 was located in the northeastern Coastal Plain of North Carolina.

${ }^{\mathrm{z}}$ Five leafhopper and one spittlebug species making up $<2 \%$ relative abundance were grouped as other species. 
May trapping period, after which time the number of positives decreased to $27 \%$ of the $P$. irroratus insects tested. None of the P. irroratus individuals from vineyard 4 was tested in 2004.

Greenhouse transmission bioassays. Samples from plants inoculated by $O$. orbona and G. versuta were analyzed separately on two ELISA plates. Positive cutoff values for O. orbona and $G$. versuta were 0.118 and 0.209 , respectively.

Of the 77 Chardonnay vines, $53(69 \%)$ used in transmission bioassays with individually caged, field-collected $O$. orbona tested positive for $X$. fastidiosa. The highest percentage of transmissions $(92 \% ; n=12)$ resulted from adult $O$. orbona collected on 17 May. The maximum likelihood estimator of transmission probability for replicates with five adult $O$. orbona insects per plant was $0.40 \pm 0.18$ or $\approx 40 \%$ (41). Of the 57 vines inoculated by $G$. versuta, 3 tested positive for $X$. fastidiosa. The only posi- tives were from the 24 June replicate. No transmissions occurred when five adult $G$. versuta insects were caged per plant. The maximum likelihood estimator of transmission probability for replicates with seven adult $G$. versuta individuals per plant was $0.31 \pm 0.01$ (41). Immunocapture (35) followed by nested-PCR analysis confirmed transmission of $X$. fastidiosa by yielding a 500-bp amplicon from $O$. orbona and $G$. versuta inoculated plants.

Sequences from North Carolina insects. Nested PCR products $(n=46)$ isolated from insects collected in North Carolina, corresponding to a 431-bp region and containing an open reading frame fragment of a conserved hypothetical protein gene of $X$. fastidiosa and a 3' flanking region (bases 479070 to 478640 of the complete genome as published by Van Sluys et al.; protein id AA028274.1) (47) were amplified during the sequencing reaction

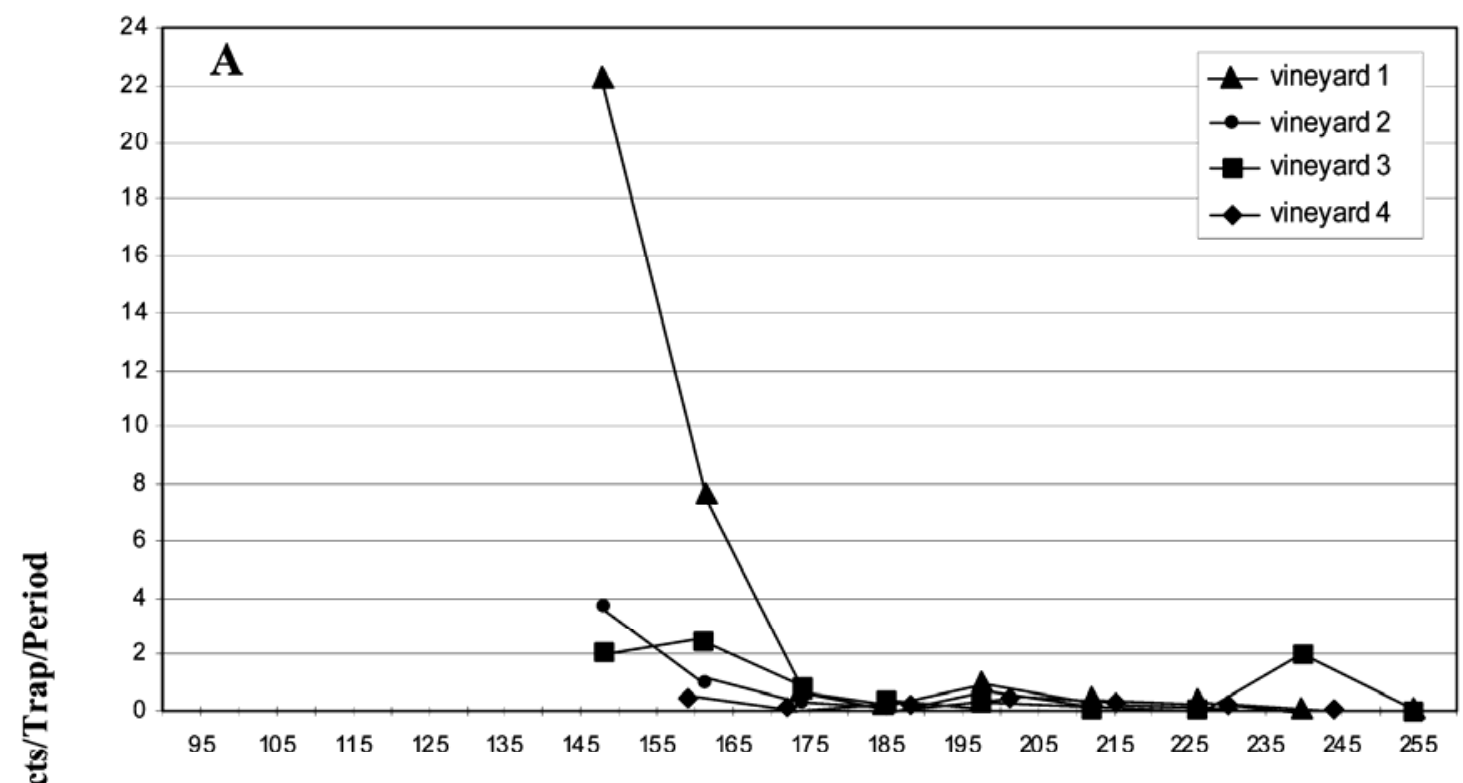

Day of the Year

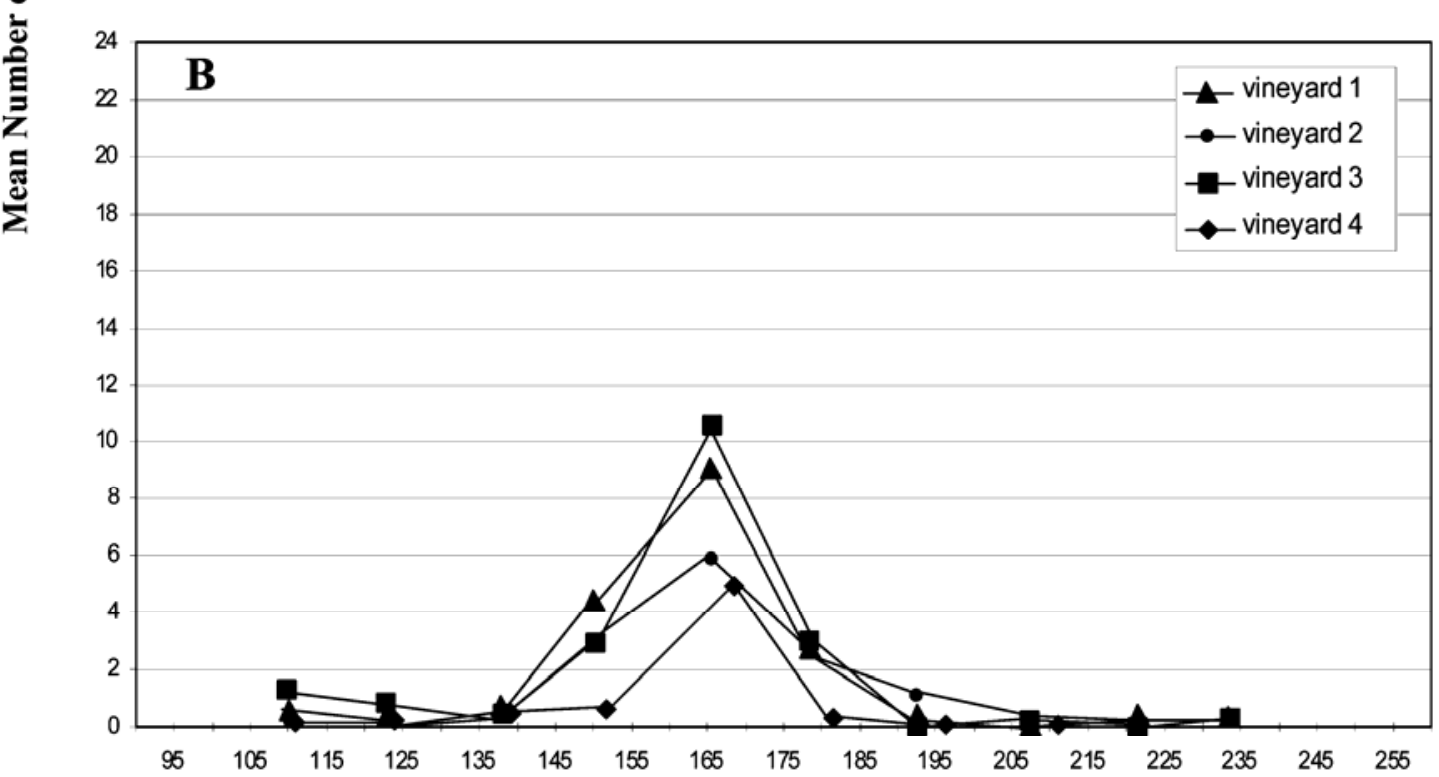

Day of the Year

Fig. 1. Adult Oncometopia orbona insects caught in vineyards 1, 2, 3, and 4 during A, 2004 and B, 2005. Each point represents mean number of insects caught per trap during each trapping period. Eight traps were placed in each vineyard. Trapping periods in vineyards 1, 2, and 3 were from days 134 to 254 in 2004 and 96 to 234 in 2005. Trapping periods in vineyard 4 were from days 146 to 259 in 2004 and 96 to 211 in 2005. 
using primers 272-1-int and 272-2-int as markers. All 46 products matched known sequences of $X$. fastidiosa strains from NCBI BLAST and additional strains were obtained in silico from grapevine (PD), almond, oleander, citrus, coffee, and Japanese beech bonsai (Table 2). Phylogenetic trees were obtained from the data by the neighbor-joining method of pairwise comparison using 1,000 bootstrap iterations and visualized with the program MEGA version 2.01 (27). The results are shown in Figure 5 using the South American CVC strain (X. fastidiosa 9a5c) as the outgroup. The dendogram shows three well-defined clades statistically supported by bootstrap procedures. All samples from North Carolina insects, with the exception of sample 4 B1 2005, grouped with the known PD strain (NC 004556.1). Insects were not differentiated by species, location, or trapping date. Neither insects from vineyard 4 nor $X$. fastidiosa samples obtained from $P$. irroratus were used in the sequence analyses.
SNAP Workbench (36) analyses confirmed the distribution of clades by grouping sequences into 12 haplotypes and three clades. The $P$ value $(P>0.05)$ for testing for pairwise genetic differentiation between insects with Hudson's tests ranked Z and $\mathrm{K}_{\mathrm{ST}}$ was not significant, indicating that $X$. fastidiosa samples from $O$. orbona and G. versuta are genetically similar (24).

\section{DISCUSSION}

The four most abundant species of leafhoppers trapped in vineyards in the central Piedmont and northeastern Coastal Plain of North Carolina were G. versuta, A. constricta, P. irroratus, and $O$. orbona Each species was captured in all four vineyards in both years, although in different amounts. Because our trapping results were consistent between years, we feel it is a good estimation of leafhopper species richness in vineyard canopies and, therefore,

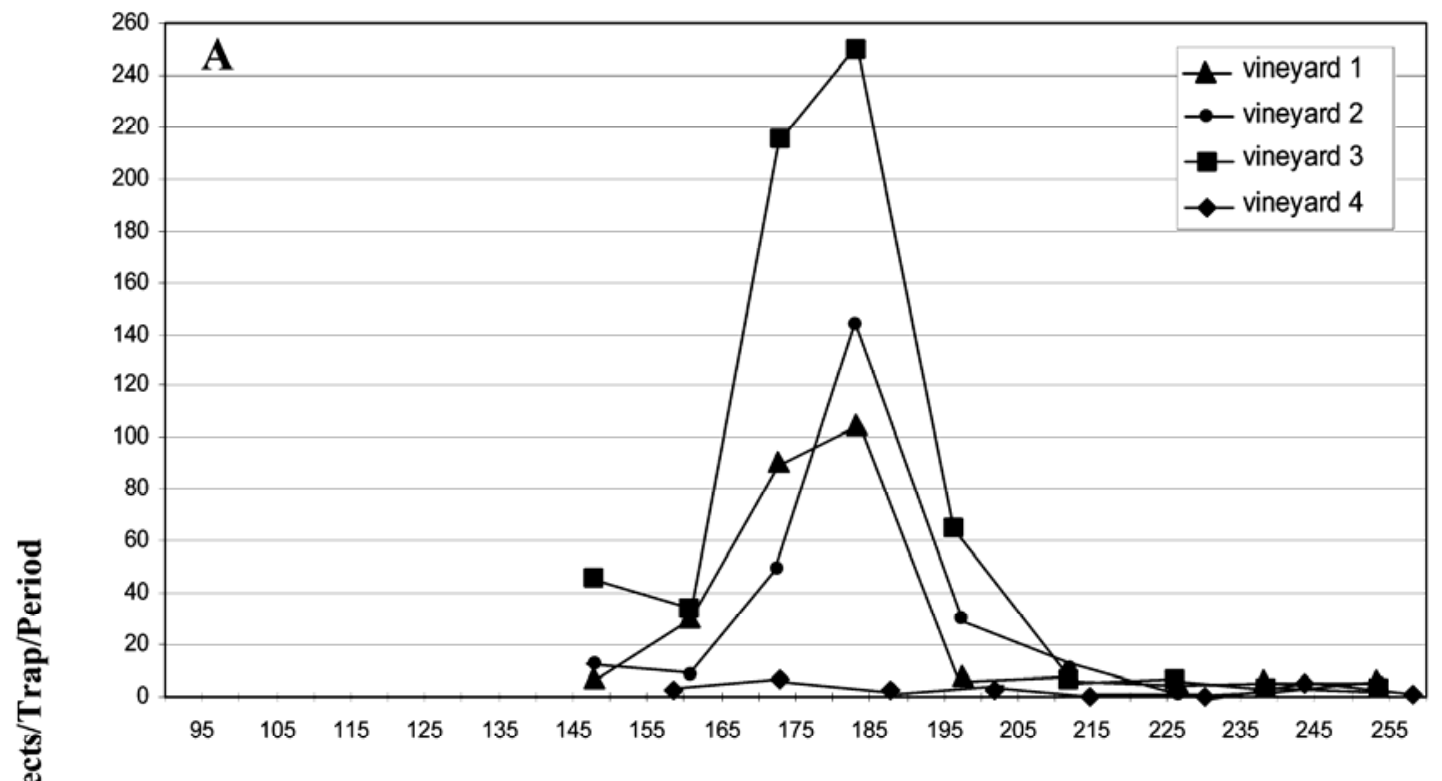

Day of the Year

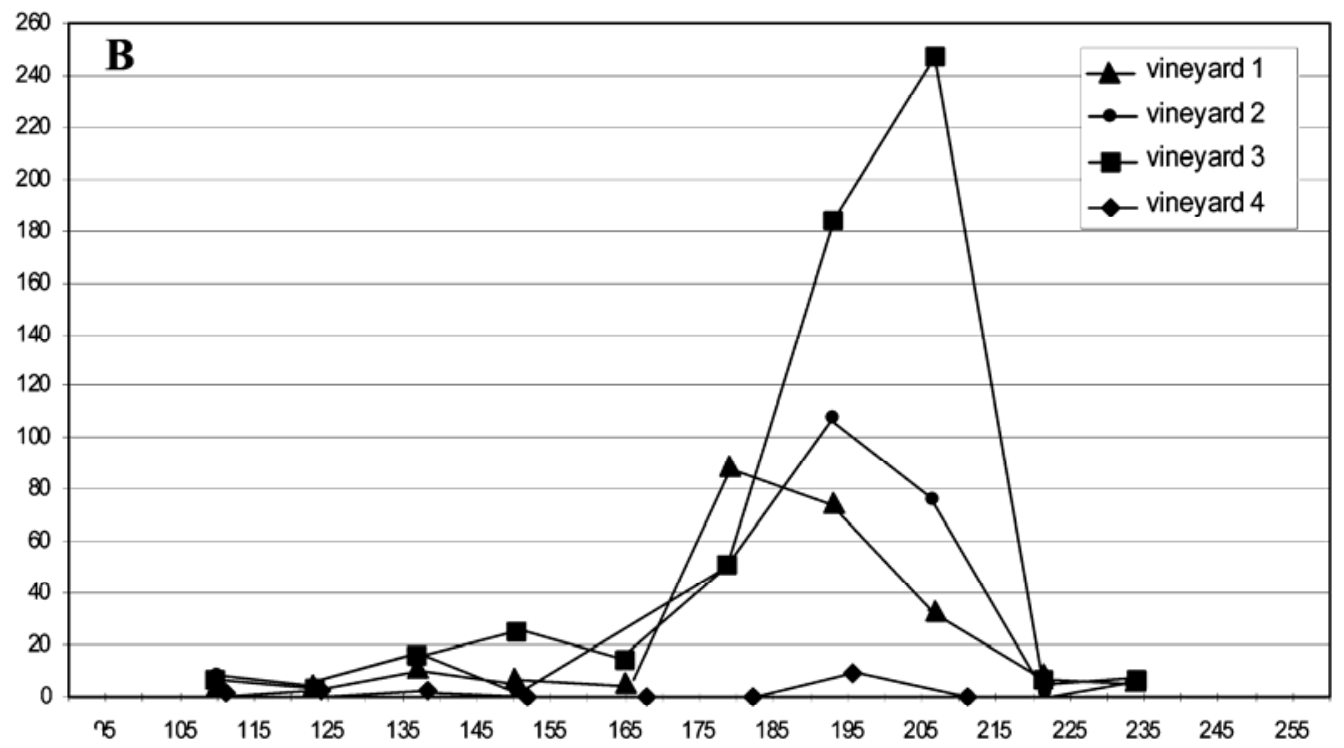

Day of the Year

Fig. 2. Adult Graphocephala versuta insects caught in vineyards 1, 2, 3, and 4 during A, 2004 and B, 2005. Each point represents mean number of insects caught per trap during each trapping period. Eight traps were placed in each vineyard. Trapping periods in vineyards 1, 2, and 3 were from days 134 to 254 in 2004 and 96 to 234 in 2005. Trapping periods in vineyard 4 were from days 146 to 259 in 2004 and 96 to 211 in 2005. 
includes the potential leafhopper vectors of $X$. fastidiosa. However, additional vector species may be present that are not attracted to yellow sticky traps.

Over the two seasons, $27 \%$ of the O. orbona, $28 \%$ of the G. versuta, and $33 \%$ of the P. irroratus trapped tested positive for $X$. fastidiosa by PCR. Additionally $O$. orbona and G. versuta transmitted $X$. fastidiosa to grape under greenhouse conditions. These results are not surprising, because work done by others has shown that members of the genera Oncometopia and Graphocephala are vectors of $X$. fastidiosa to grape $(1,14,25)$. These vectors are likely to be important in all winegrowing regions of the Southeast, because their presence has been documented throughout the southern states $(1,4,25,46)$. Glassy-winged sharpshooter is not important in North Carolina but is a serious vector in southeastern states within its geographical distribution $(1,25$, 26,46).
In our study, $O$. orbona transmitted $X$. fastidiosa to grape more efficiently than $G$. versuta. However, the $O$. orbona transmission experiments were initiated earlier, which may have resulted in the higher number of $O$. orbona-inoculated plants that ultimately tested positive for $X$. fastidiosa. In order to accurately make comparisons between species in terms of transmission efficiency, experiments need to be repeated allowing an equivalent time for symptom development, controlling $X$. fastidiosa source tissue, insect acquisition periods, and reducing variability associated with insects by using source plants artificially inoculated with $X$. fastidiosa and maintained in the greenhouse.

The trap catches of $G$. versuta, A. constricta, P. irroratus, and $O$. orbona varied between sampling years; however, their periods of peak dispersal in central Piedmont vineyards were similar in 2004 and 2005. G. versuta and $A$. constricta were the most abundant species. A. constricta was the most abundant species in
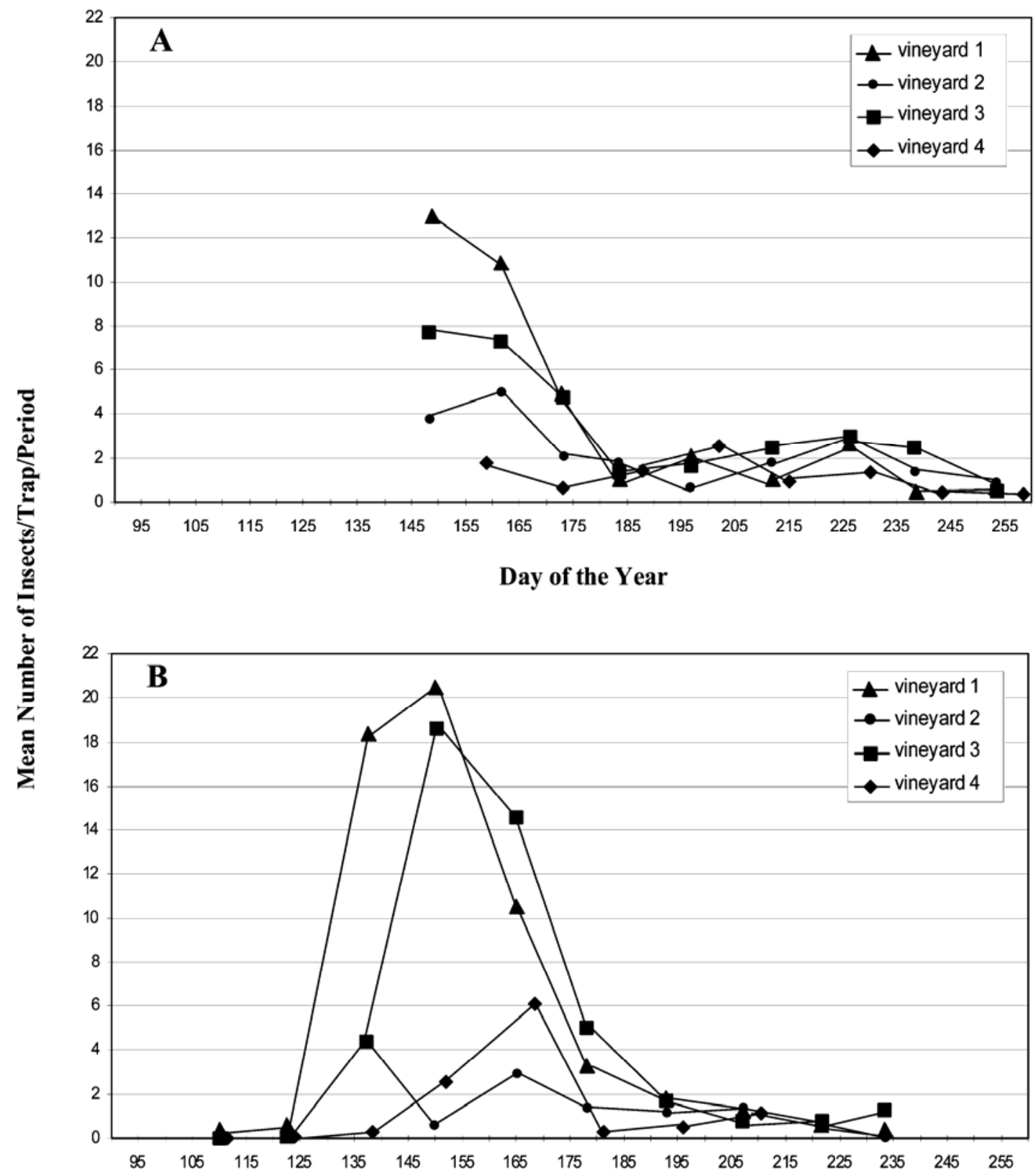

Day of the Year

Fig. 3. Adult Paraphlepsius irroratus insects caught in vineyards 1, 2, 3, and 4 during A, 2004 and B, 2005. Each point represents mean number of insects caught per trap during each trapping period. Eight traps were placed in each vineyard. Trapping periods in vineyards 1, 2, and 3 were from days 134 to 254 in 2004 and 96 to 234 in 2005. Trapping periods in vineyard 4 were from days 146 to 259 in 2004 and 96 to 211 in 2005. 
the vineyard in the northeastern Coastal Plain. Coincidentally, although the vineyard in the Coastal Plain is located in a high-risk area for PD (19), the incidence of PD is low.

In previous life history studies, $O$. orbona has been shown to complete two generations and a partial third (45) and $G$. versuta has been shown to complete three generations annually, with evidence for a partial fourth (45). At least one generation of $O$. orbona, $P$. irroratus, and $G$. versuta was identified by our trap catches. Two generations of $A$. constricta were identified in 2004; however, in 2005, a second generation was not clear, possibly because sampling was terminated too early. The seasonal patterns of $O$. orbona and $G$. versuta that we observed on grape in North Carolina were similar to those found on peach (45) and grape $(26,49)$ in Georgia. Turner and Pollard (45) found that $O$. orbona and $G$. versuta move onto peach trees in March and early April and move back to woods to overwinter in October. However, numbers of $O$. orbona and $G$. versuta trapped in vineyards in Georgia were much lower than what we trapped in North Carolina vineyards $(26,49)$. Little is known about the biology of $A$. constricta and $P$. irroratus.

TABLE 2. Xylella fastidiosa strains collected from GenBank

\begin{tabular}{lll}
\hline Strains & \multicolumn{1}{c}{ Host } & Accession number \\
\hline $9 a 5 c$ & Citrus & AE003849 \\
Ann-1 ctg125 & Oleander & AAAM03000127.1 \\
Ann-1 ctg268 & Oleander & AAAM03000001.1 \\
Dixon ctg28 & Almond & AAAL02000008.1 \\
Found-4 & Coffee & AF344190.1 \\
Found-5 & Coffee & AF344191.1 \\
JB-USNA & Japanese beech bonsai & AY196792.1 \\
Temecula1 & Grape & AE009442 \\
\hline
\end{tabular}

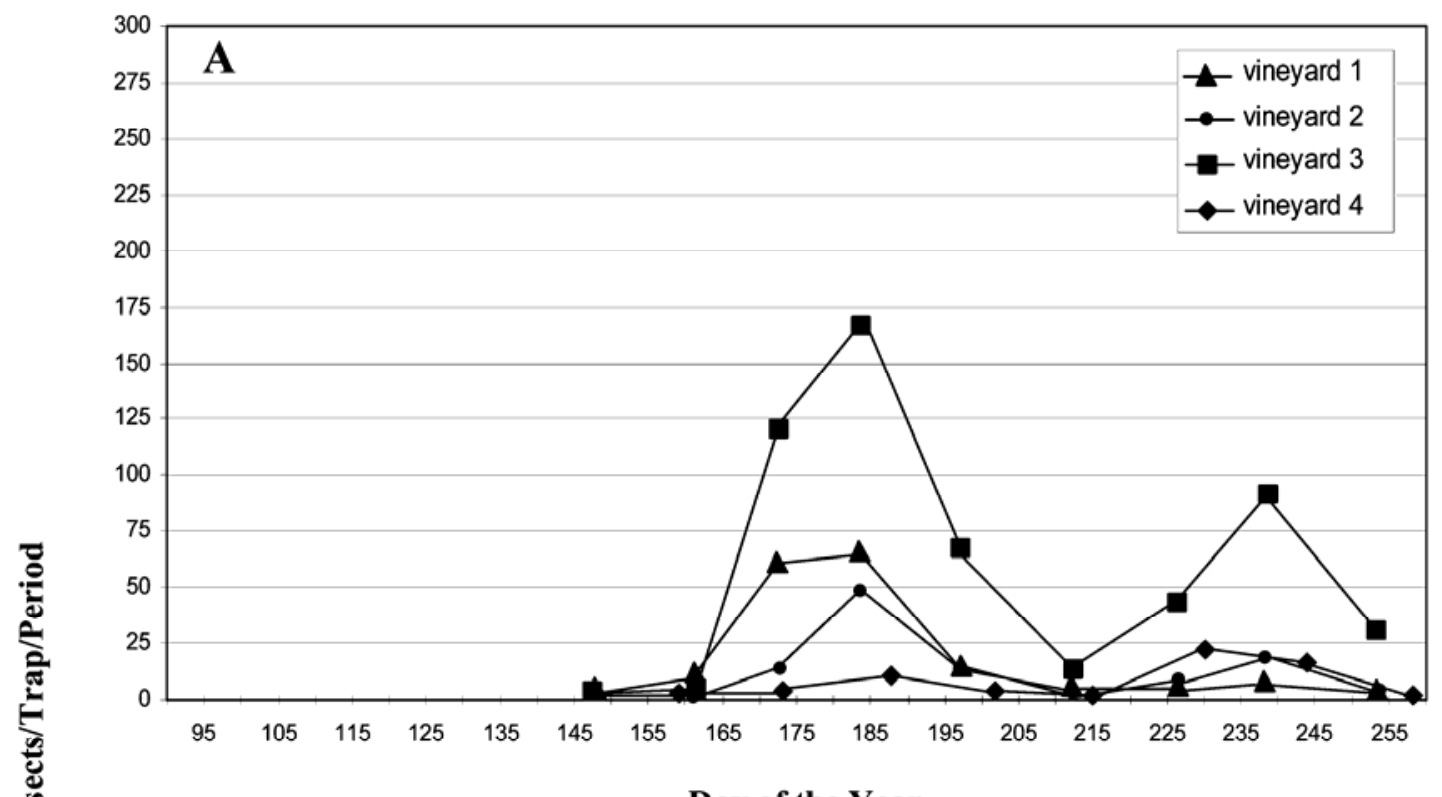

Day of the Year

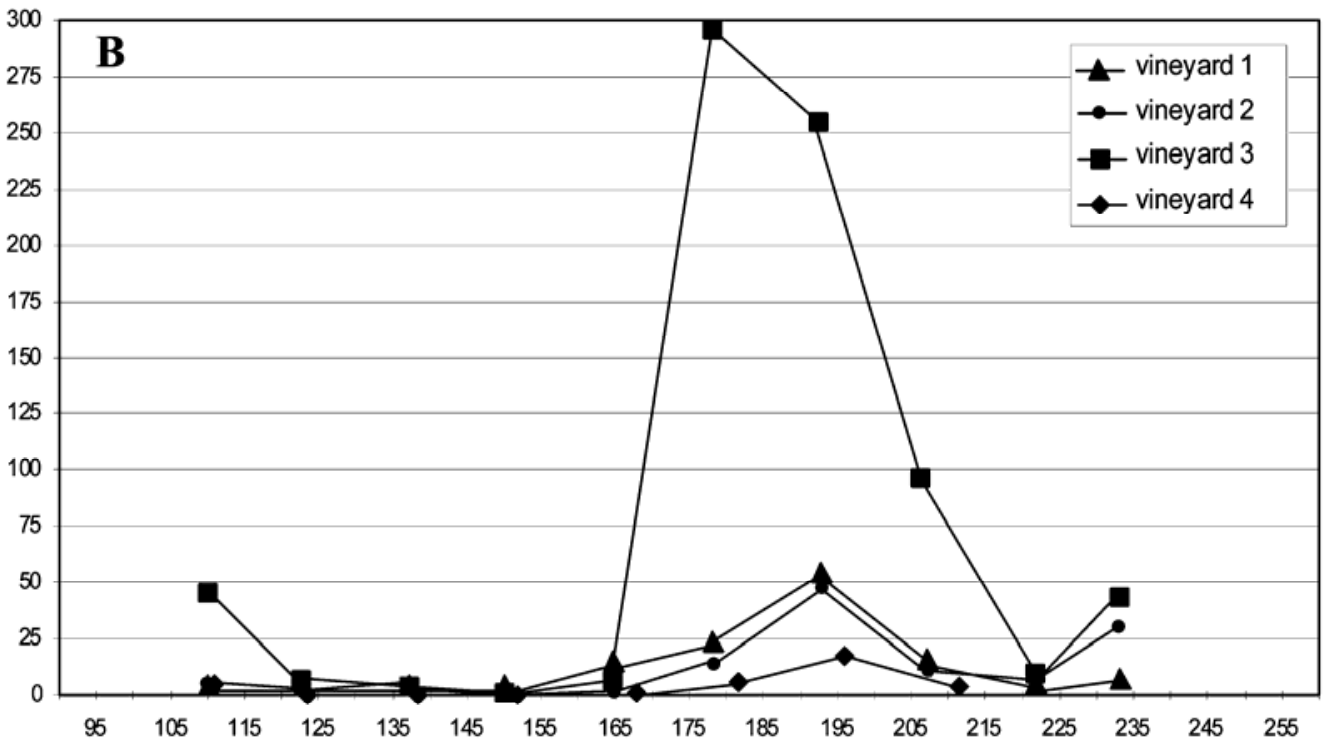

Day of the Year

Fig. 4. Adult Agalliota constricta insects caught in vineyards 1, 2, 3, and 4 during A, 2004 and B, 2005. Each point represents mean number of insects caught per trap during each trapping period. Eight traps were placed in each vineyard. Trapping periods in vineyards 1, 2, and 3 were from days 134 to 254 in 2004 and 96 to 234 in 2005. Trapping periods in vineyard 4 were from days 146 to 259 in 2004 and 96 to 211 in 2005. 
Insecticides were applied in the vineyards, with the exception of vineyard 2, after the peak number of catches for $O$. orbona and $P$. irroratus were trapped and during the peak capture intervals for $G$. versuta and A. constricta in 2004 and 2005. At vineyard 2, carbaryl (Sevin; Bayer CropScience, Durham, NC) was applied weekly during April, May, June, July, and October 2004 and 2005 to control insect pests. Insecticide use at vineyards 1,3 , and 4 consisted of one to three applications of carbaryl for Japanese beetle control. Additionally, during 2005, one application of phosmet (Imidan 70-W; Gowan Company L.L.C., Yuma, AZ) and one application of fenpropathrin (Danitol 2.4 EC; Sumitomo Chemical Company, Ltd.) were applied at vineyard 3. Insecticide applications may have affected the total leafhopper populations of $G$. versuta and $A$. constricta captured over the course of the

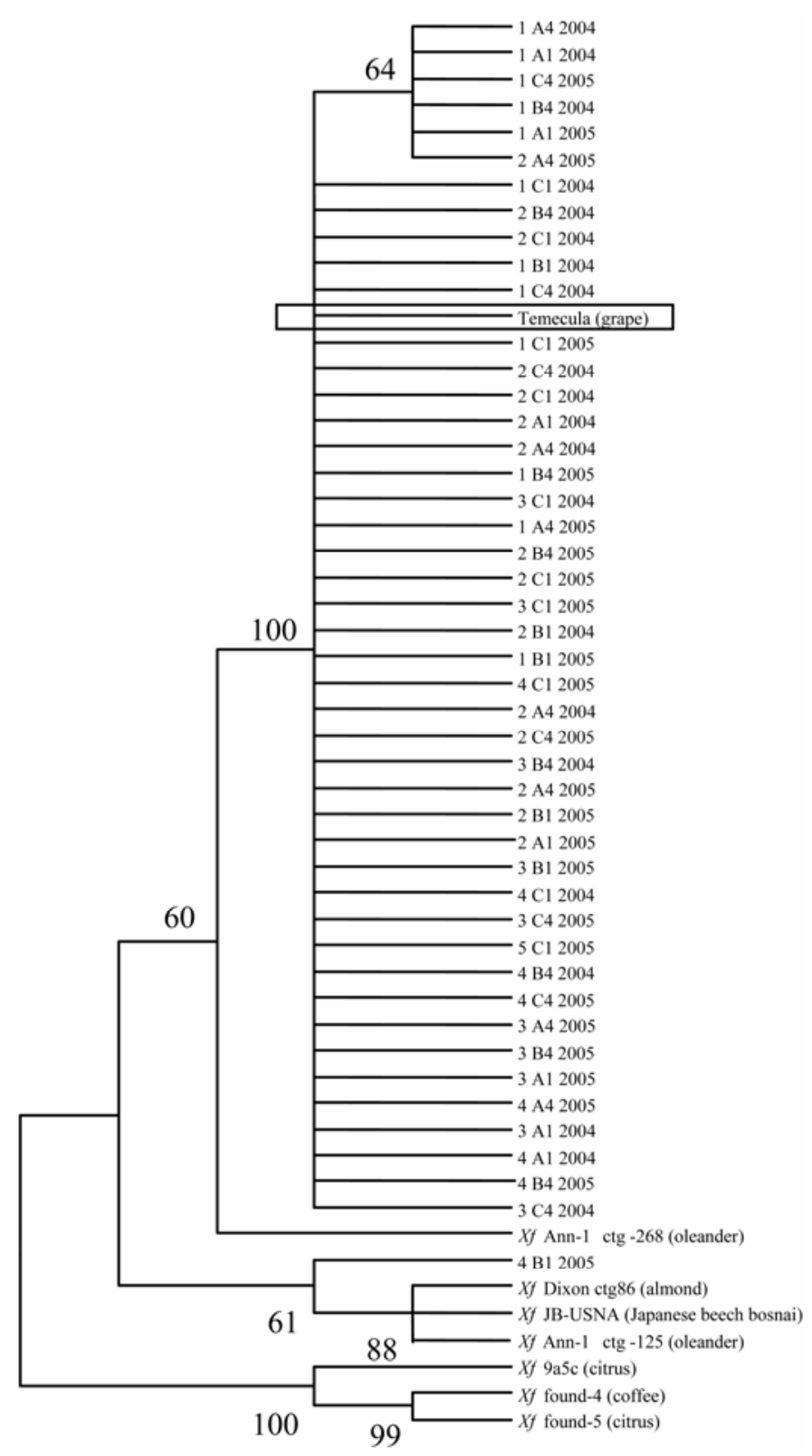

Fig. 5. Dendogram of Xylella fastidiosa samples by Neighbor-joining method. The dendogram shows relationships among 46 samples of $X$. fastidiosa from North Carolina sharpshooters and $8 X$. fastidiosa strains from host plants obtained from GenBank. A, B, and C represent vineyards 1, 2, and 3, respectively; 1 and 4 represent the sharpshooter species Oncometopia orbona and Graphocephala versuta, respectively; and 2004 and $2005=$ the year samples were collected. Multiple samples from each vineyard, sharpshooter species, and year were analyzed. Samples were amplified with 272-1-int and 272-2-int primers. season in our studies and also may have influenced the proportion of potentially infective vectors detected using nested PCR by limiting the possibility for secondary pathogen acquisition. Insecticide applications should not have affected the time of population peaks resulting from dispersal of adult insects from sources outside experimental vineyards. However, they may have altered the spatial structure of the insect populations over the season.

The species composition within vineyards may reflect the surrounding vegetation. The leafhoppers may use the herbaceous or woody plants near vineyards as secondary or oviposition hosts. Turner and Pollard (45) found that O. orbona and G. versuta, vectors of $X$. fastidiosa to peach, overwinter in hardwood forests and are generalist feeders upon many species of trees and shrubs. The leafhoppers trapped in low numbers $(<2 \%)$ may have been caught in vineyards during their migration between hosts. More research is needed to identify the host range of these insects.

Purcell (37) found that populations of the blue-green sharpshooter ( $G$. atropunctata Signoret) were highest near the perimeter of the vineyard early in the growing season. Later, newly matured adults were more evenly distributed within the vineyard. Because the yellow sticky traps used in this study were located only along the perimeter of each vineyard, traps in future studies should be located throughout the vineyard in order to fully understand the seasonal dynamics of leafhoppers in North Carolina.

Patterns of detection of $X$. fastidiosa from insect heads collected in 2004 and 2005 indicated that overwintering populations of $O$. orbona and $G$. versuta have the highest proportion of potentially infective individuals. The decline in the number of individuals positive for $X$. fastidiosa later in the season most likely reflects the mortality of overwintering adults or may reflect repeated application of broad-spectrum insecticides in some vineyards. Other studies $(15,37)$ have found that a high percentage of sharpshooters are capable of transmitting X. fastidiosa in early spring, followed by a decline in individuals testing positive during periods of nymphal development. As newly molted adults acquire $X$. fastidiosa from infected plants, percentages of infective individuals increase again into the fall. Based on this information, the most important time to control leafhopper vectors of $X$. fastidiosa in North Carolina is during the months of April, May, and June.

Early-season infection is more likely to lead to chronic infection of vines (12). In North Carolina, O. orbona populations appear to enter vineyards in late April and May and reach their population peaks by mid-May through early June. Populations of $O$. orbona were not as large as those of $G$. versuta. However, we noticed from visual observations that a higher population of $O$. orbona was present in the vineyard than was reflected on sticky traps. This might suggest that yellow sticky trap data more accurately describe the extent of immigrating insects and primary pathogen spread yet inaccurately measures insect species present in vineyards with less attraction to yellow sticky traps. The high numbers of $G$. versuta were due to a rapid population increase, typically during the last weeks of June. P. irroratus, although not a confirmed vector, also has the potential to transmit $X$. fastidiosa early in the season.

$X$. fastidiosa samples from $O$. orbona and $G$. versuta, with the exception of outlier 4 B1 2005, grouped into one clade during neighbor-joining analysis. Clades appeared to group by host, suggesting that this marker may differentiate genetically distinct populations of $X$. fastidiosa. An unrooted haplotype tree generated by SNAP workbench analyses confirmed the distribution of clades. The branching resolved by these analyses is similar to and supported by major phylogenetic groups identified in other studies based on unrelated markers $(6,28,30)$. Excluding outlier 4 B1 2005, all North Carolina insects grouped with the known PD strain from California, providing evidence that leafhoppers in North Carolina carry the grape strain of $X$. fastidiosa. Strains of $X$. fastidiosa within North America (North American strains do 
not include the citrus and coffee strains from Brazil) do not appear to differentiate based on geographic location. Nunney (30) found no evidence of geographical structure within the grape and oleander clades, suggesting strong, possibly host-driven selection. Hudson's ranked Z and KST statistical tests indicate that $X$. fastidiosa samples from $O$. orbona and $G$. versuta were genetically similar. From this information, we can speculate that $O$. orbona and $G$. versuta feed on similar plant species that support $X$. fastidiosa. Although the marker allowed a good differentiation among samples from North Carolina and databanks, a deeper resolution needs to be obtained by analyzing additional loci and multiple isolates per plant host and geographic location. Almond and oleander strains were not distinguished due to lack of sequence samples (only one per host). Phylogenetic analyses with multiple loci or satellite data may change these conclusions, because data from one locus may be due to random events.

Control of PD in California currently is based on preventing the establishment of the disease in the vineyard through vegetation management and insecticide applications (2) (A. H. Purcell, personal communication). Growers in the Southeast must be especially vigilant in early spring, when PD infection is thought to be most important (37) and when populations of known vectors $O$. orbona and $G$. versuta enter the vineyard from their overwintering hosts. Systemic, neonicotinoid insecticides are currently the most effective treatment for glassy-winged sharpshooters (2). However, effectiveness of systemic insecticides on $O$. orbona and $G$. versuta has not been fully explored. Preliminary trials showed imidacloprid applications extended the life of the vineyard by only 1 year (26). Because insecticidal sprays and rouging symptomatic vines are not highly efficient $(2,37)$, other strategies for managing PD need to be designed and implemented.

The majority of research on PD has been in California and Florida. In addition to continuing to identify and monitor vectors, a list of the most important plant hosts of X. fastidiosa and the insect vectors in the upper Southeast needs to be documented. From this study, we now know that three of the four most abundant leafhoppers present in North Carolina vineyards, O. orbona, $G$. versuta, and $P$. irroratus, carry $X$. fastidiosa in their mouthparts, and $O$. orbona and $G$. versuta transmit $X$. fastidiosa to grape. These same leafhoppers are found throughout the Southeast. The overwintering populations epidemiologically may be the most important (based on the percentage of positives) in initiating early-season infections that have a greater chance of becoming systemic. $O$. orbona is most likely the vector of greatest concern because it enters vineyards early in the spring and feeds on shoots, allowing $X$. fastidiosa more time to colonize the grapevine. Additional tests need to be done to determine whether $P$. irroratus, which is a known vector of phytoplasmas $(7,16)$, can also transmit $X$. fastidiosa.

\section{ACKNOWLEDGMENTS}

This research is made possible by funding from the North Carolina Agricultural Foundation and the North Carolina Grape Council. We thank D. Ritchie, O. Anas, T. Grandy, and D. Stephan for their wonderful assistance; and T. Cloer, P. Cloer, W. Butler, G. Strikleather, D. Strikleather, and D. Martin for permitting research in their vineyards.

\section{LITERATURE CITED}

1. Alderz, W. C., and Hopkins, D. L. 1979. Natural infectivity of two sharpshooter vectors of Pierce's disease of grape in Florida. J. Econ. Entomol. 72:916-919.

2. Anonymous. Agriculture and Natural Resources, revised 2005. University of California Statewide IPM Program, Univ. Calif. ANR Publ. 3448.

3. Aylor, D., Price, E. W., and Carbone, I. 2004. SNAP Combine and Map. Distributed over the Internet, http://snap.cifr.ncsu.edu, Department of Plant Pathology, North Carolina State University.
4. Beanland, L., Noble, R., and Wolf, T. K. 2006. Spatial and temporal distribution of North American grapevine yellows disease and of potential vectors of the causal phytoplasmas in Virginia. Environ. Entomol. 35:332-344.

5. Bextine, B., Blua, M. J., and Redak, R. 2004. Developing a method to detect Xylella fastidiosa in the glassy-winged sharpshooter. Pages 249252 in: Proc. 2004 Pierce's Dis. Res. Symp. California Department of Food and Agriculture, Sacramento, CA.

6. Chen, J., and Civerolo, E. L. 2004. Developing a microarray-PCR-based identification and detection system for Xylella fastidiosa strains important to California. Pages 171-174 in: Proc. 2004 Pierce's Dis. Res. Symp. California Department of Food and Agriculture, Sacramento, CA.

7. Chiykowski, L. N. 1965. Transmission of clover phyllody virus by the leafhopper Paraphlepsius irroratus (Say). Can. Entomol. 97:1171-1173.

8. Davis, M. J., French, W. J., and Schaad, N. W. 1981. Axenic culture of the bacteria associated with phony disease of peach and plum leaf scald. Curr. Microbiol. 6:309-314.

9. Davis, M. J., Purcell, A. H., and Thomson, S. V. 1978. Pierce's disease of grapevines: Isolation of the causal bacterium. Science 199:78-77.

10. DeLong, D. M. 1948. The leafhoppers, or Cicadellidae, of Illinois (Eurymelinae-Balcluthinae). Ill. Nat. Hist. Surv. Bull. 24(2):91-376.

11. Esau, K. 1948. Anatomic effects of the virus of Pierce's disease and phony peach. Hilgardia 18:423-482.

12. Feil, H., Feil, W. S., and Purcell, A. H. 2003. Effects of date of inoculation on the within-plant movement of Xylella fastidiosa and persistence of Pierce's disease within field grapevines. Phytopathology 93:244-251.

13. Felsenstein, J. 1993. PHYLIP (Phylogeny Inference Package) version 3.5c. Distributed by the author. Department of Genetics, University of Washington, Seattle.

14. Frazier, N. W., and Freitag, J. H. 1946. Ten additional leafhopper vectors of grape as determined by insect transmission. Phytopathology 36:634637.

15. Freitag, J. H., and Frazier, N. W. 1954. Natural infectivity of leafhopper vectors of Pierce's disease virus of grape in California. Phytopathology 44:7-11.

16. Gilmer, R. M., Palmiter, D. H., Schaefers, G. A., and McEwen, F. L. 1966. Leafhopper transmission of X-disease virus of stone fruits in New York. N. Y. State Agric. Exp. (Geneva) Bull. 813:22.

17. Gubler, W. D., Stapleton, J. J., Leavitt, G. M., Purcell, A. H., Varela, L. G., and Smith, R. J. 2005. UC IPM Pest Management Guidelines: Grape. Univ. Calif. ANR Publ. 3448.

18. Hall, T. A. 1999. BioEdit: A user-friendly biological sequence alignment editor and analysis program for Windows 95/98/NT. Nucleic Acids Symp. Ser. 41:95-98.

19. Harrison, U. J., Anas, O., and Sutton, T. B. 2002. Geographical distribution of Pierce's disease in North Carolina's winegrowing region. (Abstr.) Phytopathology 92:S35.

20. Hopkins, D. L. 1976. Pierce's disease of grapevines. Am. Wine Soc. J. 8:26-27.

21. Hopkins, D. L. 1977. Diseases caused by leafhopper-borne rickettsia-like bacteria. Annu. Rev. Phytopathol. 17:277-294.

22. Hopkins, D. L. 1981. Seasonal concentration of the Pierce's disease bacterium in grapevine stems, petioles, and leaf veins. Phytopathology 71:415-418.

23. Hudson, R. R. 2000. A new statistic for detecting genetic differentiation. Genetics 155:2011-2014.

24. Hudson, R. R., Boos, D. D., and Kaplan, N. L., 1992. A statistical test for detecting geographic subdivision. Mol. Biol. Evol. 9:138-151.

25. Kaloostian, G. H., Pollard, H. N., and Turner, W. F. 1962. Leafhopper vectors of Pierce's disease virus in Georgia. Plant Dis. Rep. 46:292.

26. Krewer, G., Dutcher, J. D., and Chang, C. J. 2002. Imidacloprid insecticide slows development of Pierce's disease in bunch grapes. J. Entomol. Sci. 37:101-112.

27. Kumar, S., Tamura, K., and Nei, M. 1993. MEGA: Molecular Evolutionary Genetics Analysis. Pennsylvania State University, University Park.

28. Lin, H., and Walker, A. 2004. Development of SSR markers for genotyping and assessing the genetic diversity of Xylella fastidiosa in California. Pages 206-209 in: Proc. 2004 Pierce's Dis. Res. Symp. California Department of Food and Agriculture, Sacramento, CA.

29. Markwordt, J. D., Doshi, R., and Carbone, I. 2004. SNAP Clade and Matrix. Distributed over the Internet, http://snap.cifr.ncsu.edu, Department of Plant Pathology, North Carolina State University.

30. Nunney, L. 2004. Genome-wide identification of rapidly evolving genes in Xylella fastidiosa: Key elements in the systematic identification of host strains, and in the search for plant-host pathogenicity candidate genes. Pages 220-224 in: Proc. 2004 Pierce's Dis. Res. Symp. California Department of Food and Agriculture, Sacramento, CA.

31. Page, R. D. M. 1996. TREEVIEW: An application to display phylogenetic trees on personal computers. Comput. Appl. Biosci. 12:357-358.

32. Pierce, N. B. 1882. The California vine disease. U.S. Dep. Agric. Div. Veg. Pathol. Bull. No. 2. 
33. Poole, R. W., Garrison, R. W., McCafferty, W. P., Otte, D., and Stark, B. P. 1997. Nomain Insecta Nearctica, A Check List of the Insects of North America. Vol. 4: Non-Holometabolous Orders. Entomological Information Services, Rockville, MD.

34. Pooler, M. R., and Hartung, J. S. 1995. Specific PCR detection and identification of Xylella fastidiosa strains causing citrus variegated chlorosis. Curr. Microbiol. 31:377-381.

35. Pooler, M. R., Myung, I. S., Bentz, J., Sherald, J., and Hartung, J. S. 1997. Detection of Xylella fastidiosa in potential insect vectors by immunomagnetic separation and nested polymerase chain reaction. Lett. Appl. Microbiol. 25:123-126.

36. Price, E. W., and Carbone, I. 2005. SNAP: workbench management tool for evolutionary population genetic analysis. Bioinformatics 21:402-404.

37. Purcell, A. H. 1975. Role of the blue-green sharpshooter, Hordnia circellata, in the epidemiology of Pierce's disease of grapevines. Environ. Entomol. 4:745-752.

38. Purcell, A. H., and Hopkins, D. L. 1996. Fastidious xylem-limited bacterial plant pathogens. Annu. Rev. Phytopathol. 34:131-151.

39. Redak, R. A., Purcel, A. H., Lopes, J. R. S., Blua, M. J., Mizell, R. F., and Anderson, P. C. 2004. The biology of xylem fluid-feeding insect vectors of Xylella fastidiosa and their relation to disease epidemiology. Annu. Rev. Entomol. 49:243-270.

40. Severin, H. H. P. 1950. Spittle-insect vectors of Pierce's disease virus. II. Life histories and virus transmission. Hilgardia 19:357-382.

41. Swallow, W. H. 1985. Group testing for estimating infection rates and probabilities of disease transmission. Phytopathology 75:882-889.

42. Swofford, D. L. 1998. PAUP*. Phylogenetic Analysis Using Parsimony (* and other Methods), Version 4.0. Sinauer Associates, Sunderland, MA.

43. Thompson, J. D., Gibson, T. J., Plewniak, F., Jeanmougin, F., and
Higgins, D. G. 1997. The ClustalX windows interface: Flexible strategies for multiple sequence alignment aided by quality analysis tolls. Nucleic Acids Res. 24:4876-4882.

44. Thompson, J. D., Higgins, D. G., and Gibson T. J. 1994. CLUSTAL W: Improving the sensitivity of progressive multiple sequence alignment through sequence weighting, position-specific gap penalties and weight matrix choice. Nucleic Acids Res. 22:4673-4680.

45. Turner, W. F., and Pollard, H. N. 1959. Life histories and behavior of five insect vectors of phony peach disease. U.S. Dep. Agric. Tech. Bull. No. 1188.

46. Turner, W. F., and Pollard, H. N. 1959. Insect transmission of phony peach disease. U.S. Dep. Agric. Tech. Bull. 1193.

47. Van Sluys, M. A. 2003. Comparative analyses of the complete genome sequences of Pierce's disease and citrus variegated chlorosis strains of Xylella fastidiosa. J. Bacteriol. 185:1018-1026.

48. Wells, J. M., Raju, B. C., Hung, H. Y., Weisburg, W. G., Mandelco-Paul, L., and Brenner, D. J. 1987. Xylella fastidiosa gen. nov. sp. nov.: Gramnegative, xylem-limited fastidious plant bacteria related to Xanthomonas spp. Int. J. Syst. Bacteriol. 37:136-143.

49. Yonce, C. E. 1983. Geographical and seasonal occurrence, abundance, and distribution of phony peach disease vectors and vector response to age and condition of peach orchards and a disease host survey of Johnsongrass for rickettsia-like bacteria in the Southeastern United States. J. Ga. Entomol. Soc. 18:410-418.

50. Young, D. A. 1968. Taxonomic study of the Cicadellinae (Homoptera: Cicadellidae). Part 1: Proconiini. Smithson. Inst. Bull. 261-287.

51. Young, D. A. 1977. Taxonomic study of the Cicadellinae (Homoptera: Cicadellidae). Part 2: New World Cicadellini and the genus Cicadella. N. C. Agric. Exp. Stn. Bull. 235:1135. 